\title{
Role of LPS-activated Macrophages in the Differentiation of Mesenchymal Stem Cells into Smooth Muscle Cells
}

\author{
Mi Jeong Lee, Eun Kyoung Do and Jae Ho Kim* \\ Department of Physiology, School of Medicine, Pusan National University, Yangsan 626-870, Korea
}

Received November 13, 2012 /Revised December 22, 2012 /Accepted December 31, 2012

\begin{abstract}
Human adipose-derived mesenchymal stem cells (hMSCs) are highly useful for vascular regeneration of injured or inflamed tissue. Lipopolysaccharide (LPS) is a potent activator of macrophages and stimulates macrophages to release inflammatory cytokines. In the present study, we explored the role of LPS-activated macrophages in the differentiation of hMSCs to smooth muscle cells (SMCs). We demonstrated that conditioned medium from LPS-induced macrophages (LPS CM) stimulates differentiation of hMSCs to SMCs, as evidenced by increased expression of smooth muscle-specific markers, including alpha-smooth muscle actin (a-SMA), smooth muscle-myosin heavy chain, and calponin. LPS induced the secretion of PGF2a from macrophages, and PGF2a treatment stimulated expression levels of SMC-specific markers in hMSCs. Furthermore, small interfering RNA-mediated silencing of the PGF2 $a$ receptor inhibited LPS CM-stimulated a-SMA expression. These results suggest that LPS-activated macrophages promote differentiation of hMSCs to SMCs through a PGF2a-dependent mechanism.
\end{abstract}

Key words : Mesenchymal stem cells, lipopolysaccharide, macrophages, smooth muscle cells, alphasmooth muscle actin (a-SMA)

\section{서 론}

중간엽 줄기세포(mesenchymal stem cells)는 지방, 골수, 혈 액에서 분리 가능하며 자가 재생 능력이 있는 성체 줄기세포 의 일종이다[2, 5]. 또한 중간엽 줄기세포는 지방세포, 골세포, 근육 세포 등 여러 형태의 세포로 분화될 수 있다 $[5,20,21$, 23]. 특히, 최근 연구 결과를 살펴 보면, 중간엽 줄기세포는 생체 내로 이식 했을 때 주변 미세 환경에 따라 조직 특이적인 세포 형태(tissue-specific cell type)로 분화가 되며, 이러한 특 징으로 인해 중간엽 줄기세포는 심근경색, 사지 허혈 등 손상 된 조직의 재생 및 치유에 효과가 있는 것으로 보고 되고 있다 $[7,8]$. 중간엽 줄기세포는 손상된 조직의 재생을 위해 유용한 세포치료제로 관심의 대상이 되고 있다[17, 18]. 최근 연구 결 과에서는 인체 지방조직에서 분리한 중간엽 줄기세포는 허혈 조직이나 염증성 조직으로 이동하여 혈관 형성 인자들을 분비 하고, 혈관 형성을 도와 상처조직 치유 및 조직 재생 과정에 효과가 있는 것으로 보고 되고 있다 $[1,6,16,18,19,22]$.

Lipopolysaccharide (LPS)는 면역 세포들을 활성화시키는 주요한 물질로 알려져 있으며, 강력한 맹독성 인자로 급성 염

\section{*Corresponding author}

Tel : +82-51-510-8073, Fax : +82-51-510-8076

E-mail : jhkimst@pusan.ac.kr

This is an Open-Access article distributed under the terms of the Creative Commons Attribution Non-Commercial License (http://creativecommons.org/licenses/by-nc/3.0) which permits unrestricted non-commercial use, distribution, and reproduction in any medium, provided the original work is properly cited.
증 반응을 일으킨다 $[5,11]$. LPS에 노출되면 IL- $1 a$, IL-1 $\beta$, IL-8, $\mathrm{TNF}-\mathrm{a}$ 와 같은 염증성 사이토카인(pro-inflammatory cytokines)의 분비가 촉진되어 염증 반응이 유발된다 $[4,5,11,13$, 25].

본 연구에서는 염증 상태에서 존재하는 중간엽 줄기 세포가 혈관 형성에 관여하는지 알아보고, 염증 상태에서 줄기세포의 역할을 규명하고자 본 연구를 진행하였다. 생체 내 염증 상태 와 유사한 환경을 만들고자, 강력한 염증 유발 물질인 LPS를 대식세포에 처리하여 그 배양액을 회수하였다. LPS 배양액 (LPS-conditioned medium, LPS CM)을 중간엽 줄기세포에 처 리하여 혈관벽을 이루는 중요한 구성원의 하나인 평활근 세포 로의 분화 여부를 관찰하였다. 또한 LPS 배양액 내에 존재하 는 분화 유도 물질을 찾아 내었다. 본 연구는 염증성 미세환경 내에 존재하는 중간엽 줄기세포가 평활근 세포로 분화가 유도 됨을 확인하였고, 혈관 형성을 촉진하는데 영향을 미칠 것으 로 사료된다.

\section{재료 및 방법}

시약

본 연구에 사용된 a-minimum essential medium (a-MEM), Hank's buffered salt solution, trypsin, fetal bovine serum, Lipofectamine 2000은 Invitrogen (Carlsbad, CA, USA)사에서 구입하여 사용하였다. 인간유래 재조합 TGF- $\beta 1$ 단백질은 $\mathrm{R} \& \mathrm{D}$ (Minneapolis, $\mathrm{MN}, \mathrm{USA}$ )사에서 구입하여 사용하였다. PGF2a enzyme immunoassay (EIA) kit, U46619, SQ29548은 
Cayman Chemical (Ann Arbor, MI, USA)사에서 구입하여 사용하였다. Trizol, LPS, lysophosphatidic acid (LPA), Ki16425와 a-SMA, calponin에 대한 항체는 Sigma-Aldrich (St Louis, MO, USA)사에서 구입하여 사용하였다. Smooth muscle-myosin heavy chain (SM-MHC), smoothelin, GAPDH 항 체는 Millipore (Billerica, MA, USA)사에서 구입하여 사용하 였다.

\section{세포 배양법}

인체 피하지방 조직을 수술적 방법을 통하여 환자에게서 채취하였으며 부산 대학교 병원 IRB에 의해 승인 받은 환자의 샘플을 이용하였다. 인체 중간엽 줄기세포를 분리하기 위하여 환자의 지방 조직을 멸균된 생리식염수에 세 번 세척한 후 collagenase type I을 처리하여 $37^{\circ} \mathrm{C}$ 에서 한 시간 방치한다. $3,000 \mathrm{rpm}$ 에서 10 분간 원심분리 한 후 상층액은 버리고, 침전 물만 모아 $10 \%$ fetal bovine serum이 포함된 a-MEM배지에 배양한다. 세포 밀도가 $70 \%$ 정도가 되면 계대 배양을 하도록 한다. Raw 264.7 대식세포는 $10 \mathrm{~mm}$ petri-dish에서 10\% fetal bovine serum가 포함된 DMEM배지에 배양한다. $80 \%$ 밀도가 되면 계대 배양 하도록 한다. LPS를 처리하여 활성화된 대식 세포로부터 배양액을 얻기 위해서 대식세포에 $2 \mu \mathrm{g} / \mathrm{ml}$ 농도 의 LPS를 함유한 DMEM배지를 48 시간 동안 처리한 후 배지 를 $3,000 \mathrm{rpm}$ 에서 5 분간 원심분리하여 상층액을 채취한다. 이 런 과정을 통해 확보된 LPS 배양액은 e-tube에 분주한 후 실험 을 위해 $-80^{\circ} \mathrm{C}$ 냉동고에 저장하여 보관한다.

\section{Western blot analysis}

$60 \mathrm{~mm}$ dish에 $5 \times 10^{4}$ 개수의 중간엽 줄기세포를 $50 \%$ 정도 의 밀도가 되도록 배양하였다. 기존의 배양액을 제거하고 LPS 배양액을 농도 별로 처리하여 96시간 동안 배양하였다. 세포 내 단백질 발현양을 조사하기 위해 세포 배양액을 제거한 후 $1 \mathrm{ml}$ 의 lysis buffer를 넣고 세포를 scraper로 긁어 모아 초음파 분쇄기를 이용해 세포를 파쇄한다. 세포 용해액을 e-tube에 옮긴 후 $4^{\circ} \mathrm{C}$ 에서 $15,000 \mathrm{rpm}$ 으로 15 분간 원심분리 하여 단백 질을 분리하였다. 추출한 단백질은 정량하여 $5 \times$ sample buffer 와 함께 섞어 $95^{\circ} \mathrm{C}$ 에서 5 분간 가열한 후 $10 \%$ SDS-PAGE gel로 전기 영동하고, nitrocellulose membrane위로 전기적으로 이 동시켰다. 다양한 일차 항체와 반응시키고, 이차 항체를 각각 반응시켰다. 항체들의 발현 분석은 horseradish peroxidase가 결합된 이차항체에 의해 발현되는 ECL western blot analysis 시스템을 이용하여 결과를 분석하였다.

\section{PGF2a 측정법}

Raw 264.7 대식세포를 $10 \mathrm{~mm}$ petri-dish에서 $80 \%$ 밀도가 되도록 키운다. 배양액을 버리고, Hank's balance salt solution 으로 두 번 세척한 후, $2 \mu \mathrm{g} / \mathrm{ml}$ LPS를 넣거나 넣지않은 10 $\mathrm{ml}$ DMEM배지를 각각 48 시간 배양한다. 48 시간 이후 배양액 을 $15 \mathrm{ml}$ tube에 모은 뒤 원심분리 하여 상층액을 회수한다. PGF2a의 농도 측정은 PGF2a EIA Kit를 이용하여 LPS 배양핵 에 존재하는 PGF2a의 농도를 측정하였다. 각 시료들은 ELISA reader에서 $450 \mathrm{~nm}$ 에서의 O.D. 값을 측정하였다.

Transfection with small interference RNA (siRNA)

중간엽 줄기세포를 회수하여 세포수가 $1 \times 10^{5}$ 가 되도록 분 주하여 $1.5 \mathrm{ml}$ tube에 모아 둔다. siRNA와 Lipofectamine 2000 를 섞어 15 분간 상온에서 방치한 후 $100 \mathrm{nM}$ 농도로 중간엽 줄기세포에 처리한다. 4 시간 후 $10 \%$ fetal bovine serum이 포 함된 a-MEM으로 교환해준 후 $37^{\circ} \mathrm{C}$ 조건에서 24 시간 동안 배양한다. siRNA에 의한 FP 유전자의 발현감소여부는 RT$\mathrm{PCR}$ 방법으로 확인하였다.

\section{RT-PCR}

Total cellular RNA는 TRIzol 시약을 사용하여 제조사의 지 침에 따라 분리하였다. 분리된 total RNA $2 \mu \mathrm{gg}$ 에 200 UM-MLV reverse transcriptase, $0.5 \mu \mathrm{g}$ Oligo (dT) 15 primer (Promega, Madison, WI)를 섞어 cDNA를 제조하였다. cDNA 는 아래의 primer들을 이용한 PCR 방법으로 증폭되었다. GAPDH 5'-TCCATGACAACTTTGGTATCG-3' (sense), 5'-TGTAGCCAAATTCGTTGTCA-3' (anti-sense) ; prostaglandin $\mathrm{F}_{2 a}$ receptor (FP) 5'-CTTCATGACAGTGGGAATCT (sense), 5'-CCAAAAATACTGCAAAGGAC (anti-sense).

\section{통계분석}

반복실험 결과는 mean $\pm \mathrm{SD}$ 로 나타내었으며 다변량분석결 과(multivariate data)의 경우 ANOVA test를 이용해 유의성 여부를 판정하였다. $p$ 값이 0.05 이내인 경우 유의성이 있다고 판정하였다.

\section{결과 및 고찰}

대식세포(macrophage)에 LPS를 처리하여 얻은 LPS 배 양액에 의한 인체 중간엽 줄기세포의 평활근 세포로의 분화유도

본 연구에서는 LPS에 의해 활성화된 대식세포가 인체 중간 엽 줄기세포의 평활근 세포로의 분화에 영향을 미치는지 확인 하고자 하였다. 이를 위해 대식세포에 LPS를 처리한 후 48시 간 동안 배양하여 회수한 LPS 배양액을 중간엽 줄기세포에 처리하였다. LPS 배양액을 96시간 동안 중간엽 줄기세포에 처리한 후 평활근 세포로의 분화여부는 평활근 세포에 특이적 인 표지인자의 발현 여부를 western blotting을 통해 확인함으 로써 시행하였다. LPS 배양액을 처리한 군에서는 LPS 배양액 의 농도가 증가함에 따라 평활근 세포의 대표 지표인자인 a$\mathrm{SMA}$ 의 발현이 증가함을 확인할 수 있었다(Fig. 1A). 그러나, 

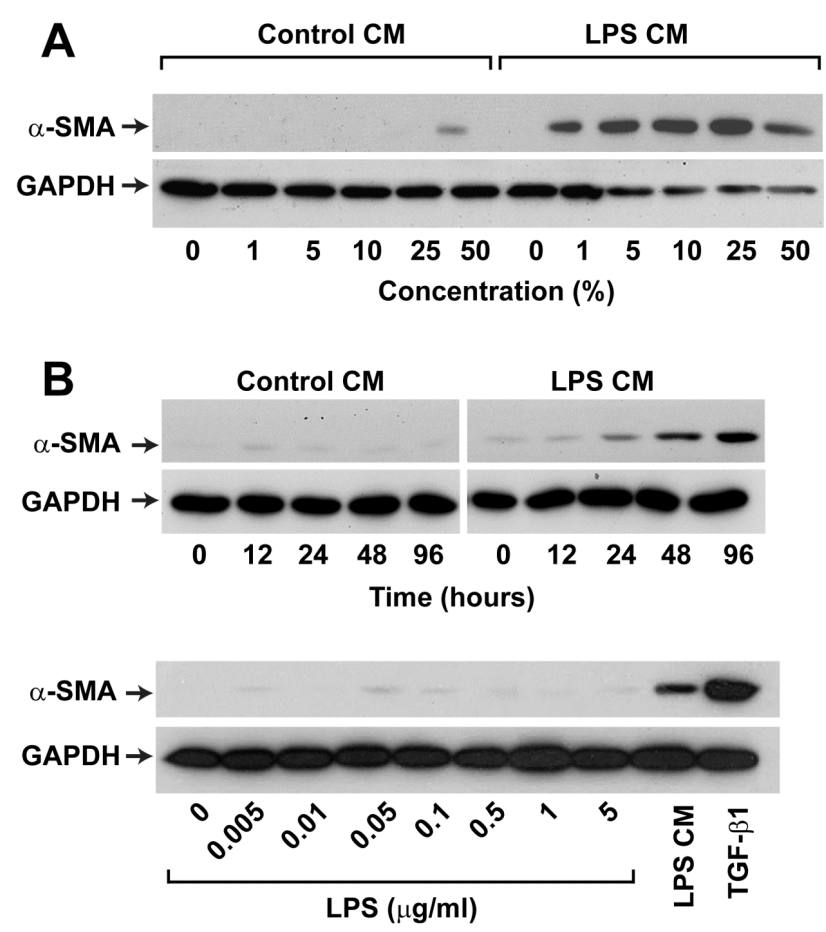

Fig. 1. Effect of LPS CM on the expression levels of a-SMA in hMSCs (A) hMSCs were treated with the indicated concentrations of vehicle, control CM or LPS CM for 4 days (B) hMSCs were treated with $10 \%$ control CM or $10 \%$ LPS CM for indicated time periods (C) hMSCs were treated with the indicated concentrations of LPS, $5 \%$ LPS CM, or $1 \mathrm{ng} / \mathrm{ml}$ TGF- $\beta 1$ for 4 days The expression levels of a-SMA and GAPDH were determined by Western blotting.

대식세포에 아무것도 처리하지 않은 후 얻은 대조군 배양액 (control $\mathrm{CM}$ )을 중간엽 줄기세포에 처리하였을 때에는 중간엽 줄기세포 내에서 a-SMA의 발현이 증가되지 않았다. 그리고 LPS 배양액을 중간엽 줄기세포에 시간 별로 처리했을 때에는 처리 후 24시간부터 a-SMA이 발현하며 96시간까지 발현이 증가하는 것을 확인하였다(Fig. $1 \mathrm{~B}$ ).

LPS 배양액에 의해 중간엽 줄기세포가 평활근 세포로의 분화가 촉진되는 것이 LPS에 의해 활성화 된 대식세포를 통 하여 일어나는 것인지 또는 LPS가 중간엽 줄기세포에 직접 적인 영향을 끼쳐서 일어나는 현상인지를 알아보고자, 중간 엽 줄기세포에 LPS를 처리한 후 a-SMA의 발현을 확인하였 다. LPS를 중간엽 줄기세포에 직접 처리했을 때에는 a-SMA 가 발현되지 않았고, 대식세포에 LPS를 처리하여 얻은 LPS 배양액을 처리한 경우에만 중간엽 줄기세포에서 a-SMA가 발현되는 것을 확인하였다(Fig. 1C). 이 결과를 통하여 LPS에 의해 활성화된 대식세포의 배양액인 LPS 배양액이 중간엽 줄기세포를 평활근 세포로 분화를 촉진시킨다는 것을 알 수 있었다.

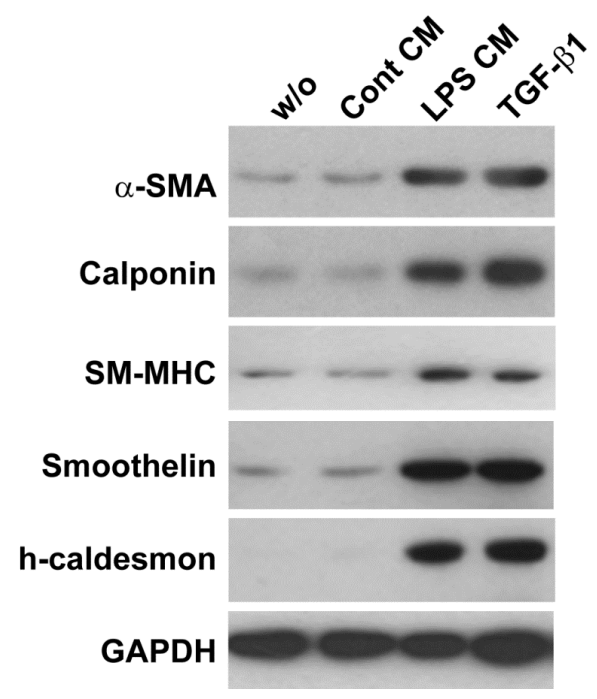

Fig. 2. Effects of LPS CM on the expression levels of smooth muscle-specific marker genes in hMSCs hMSCs were treated with vehicle, 10\% control CM (cont CM), 10\% LPS CM, or $1 \mathrm{ng} / \mathrm{ml}$ TGF- $\beta 1$ for 4 days The expression levels of a-SMA, calponin, SM-MHC, smoothelin, h-caldesmon, and GAPDH were probed by Western blotting.

LPS 배양액에 의한 다양한 평활근 세포 지표 인자의 발현 확인

중간엽 줄기 세포에 LPS 배양액을 처리 했을 때 평활근 세 포의 대표적인 지표인자인 a-SMA 이외에 다른 지표인자들도 발현이 되는지 확인하는 실험을 진행하였다. LPS 배양액을 처리했을 때 a-SMA에 뿐만 아니라 calponin, smoothelin, $\mathrm{h}$-caldesmon, SM-MHC와 같은 평활근 세포에만 특이적으로 나타나는 지표인자들이 발현되는 것을 확인하였다(Fig. 2). 본 연구결과를 통해 LPS 배양액이 중간엽 줄기세포를 평활근 세 포로의 분화를 촉진한다는 것을 다시 한번 확인할 수 있었다.

LPS 배양액의 분화 유도에 lysophosphatidic Acid (LPA) 관여 여부 확인

본 연구실에서는 LPA에 의해 중간엽 줄기세포가 평활근 세포로 분화를 유도한다는 연구 결과를 보고한 바 있다[10]. $\mathrm{LPA}$ 는 암 조직의 혈관 생성에 관여하고 암 조직의 크기를 증가시키는데 관여하는 것으로 알려져 있다 $[2,8,9]$. 특히, 난 소암 환자의 복수에 다량 존재하는 물질로써 염증성 환경에 서는 LPA가 고농도로 존재하며, 중간엽 줄기세포는 LPA 농 도가 높은 곳으로 이동한다[14]. 이런 보고를 바탕으로 LPS 배양액에 의해서 중간엽 줄기세포가 평활근 세포로 분화 됨 에 있어 LPA가 관여하는지 확인하는 실험을 진행하였다. LPA 수용체 억제제인 Ki16425로 LPA 수용체를 억제 시킨 후 LPS 배양액을 처리하여 a-SMA의 발현여부를 확인하였 다. LPA에 의해 증가 되었던 a-SMA 발현은 Ki16425의 처리 


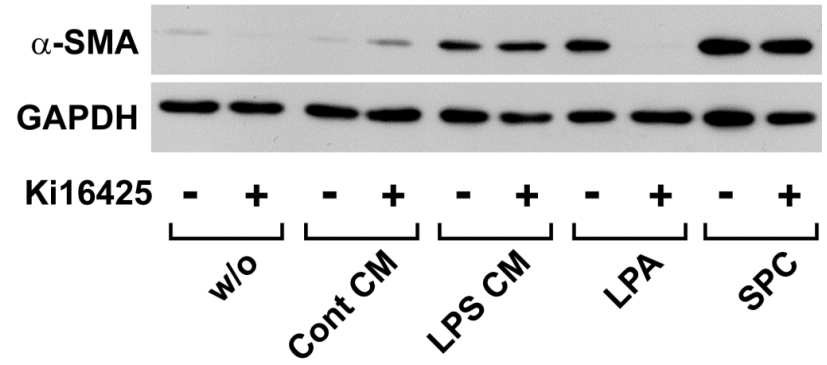

Fig. 3. LPA is not involved the LPS CM-induced a-SMA expression in hMSC Serum-starved hMSCs were treated with either $10 \mu \mathrm{M}$ 1-oleoyl-LPA, $2 \mu \mathrm{M}$ sphingosylphosphorylcholine, $10 \%$ control CM (cont CM), or 10\% LPS $\mathrm{CM}$ for 4 days in the absence or presence of $10 \mu \mathrm{M}$ Ki16425 The expression levels of a-SMA and GAPDH were determined by Western blot analysis.

시 a-SMA발현이 완전히 억제되었다. 그러나, LPS 배양액과 $\mathrm{SPC}$ 에 의해 증가한 a-SMA발현은 LPA 수용체를 억제하여 도 a-SMA발현에는 전혀 영향이 없는 것을 확인하였다(Fig. 3). 따라서 LPS 배양액에 의한 a-SMA의 발현에는 LPA가 관 여하지 않음을 알 수 있었다.

LPS에 의해 활성화 된 대식세포의 분비되는 물질 확인 및 분화 유도 확인

대식세포에 LPS를 처리하면 cyclooxygenase-2 (COX-2)의 활성화가 일어난다. 이로 인해 대사산물인 prostanoid 계열인 prostaglandin E2 ( $\left.\mathrm{PGE}_{2}\right)$, prostaglandin F2a (PGF2a)의 분비 가 촉진된다고 알려져 있다[5, 28]. 이와 같은 보고를 바탕으로 대식세포에 LPS를 48시간 처리하여 회수한 LPS 배양액에 존 재하는 PGF2a의 양을 EIA 방법을 통하여 측정해 보았다. LPS 에 의해 활성화 된 대식세포에서는 PGF2 $a$ 의 분비가 촉진된다
는 것을 알 수 있었다(Fig. $4 \mathrm{~A})$.

Thromboxan $\mathrm{A}_{2}\left(\mathrm{TxA}_{2}\right)$ 는 arachidonic acid의 대사산물인 prostanoid계의 주요한 물질로 알려져 있다. 본 연구실에서는 $\mathrm{TxA}_{2}$ 의 안정화된 유사화합물인 U46619가 중간엽 줄기세포를 평활근 세포로 분화를 유도한다고 밝힌 바 있다[12, 27]. 그리 하여, 본 실험에서 U46619가 LPS 배양액에 의한 a-SMA발현 에 관여하는 지 알아보고자 실험을 진행하였다. U46619 수용 체 억제제인 SQ29548을 중간엽 줄기세포에 전 처리하여 $\mathrm{U} 46619$ 수용체를 억제 시킨 후, LPS 배양액을 처리하여 96시 간 동안 배양시킨 후 a-SMA의 발현을 확인하였다. U46619에 의해 증가 되었던 a-SMA발현은 SQ29548의 처리 시 억제 되었 으나, LPS 배양액과 TGF- 31 에 의해 증가되었던 a-SMA의 발 현에는 SQ29548가 아무런 영향이 없는 것을 확인하였다(Fig. $4 \mathrm{C})$. 이 결과를 통해 U46619는 LPS 배양액에 의한 a-SMA의 발현에 관련이 없는 것을 알 수 있었다.

LPS 배양액에 존재하는 PGF2a에 의한 중간엽 줄기세포 의 평활근 세포로의 분화 유도 확인

PGF2a는 신장이나 폐, 또는 관상동맥의 혈관수축을 일으키 는 물질로 알려져 있으며 $[3,26]$, 당뇨병, 심혈관 질환, 간질환 등을 않고 있는 환자들의 혈액에 고농도로 존재한다[24]. 최근 연구 결과에 따르면, PGF2a는 중간엽 줄기세포를 평활근 세포 로 분화를 유도하며 상처 조직의 혈관 재생을 통한 조직 재생 에 중요한 역할을 하는 것으로 보고되었다[15]. 이런 보고를 바탕으로 LPS 배양액에 의해 중간엽 줄기세포가 평활근 세포 로 분화됨에 있어 PGF2 $a$ 가 관여하는지 알아 보는 실험을 진행 하였다. 중간엽 줄기세포에 siRNA를 이용하여 PGF2a의 수용 체인 prostaglandin F receptor $(\mathrm{FP})$ 의 발현이 억제 되는 것을 확인 하였다(Fig. $5 \mathrm{~A}$ ). 이전 보고에서 중간엽 줄기세포가 PGF2a에 의해 a-SMA발현이 증가하고, FP 수용체에 대한
A

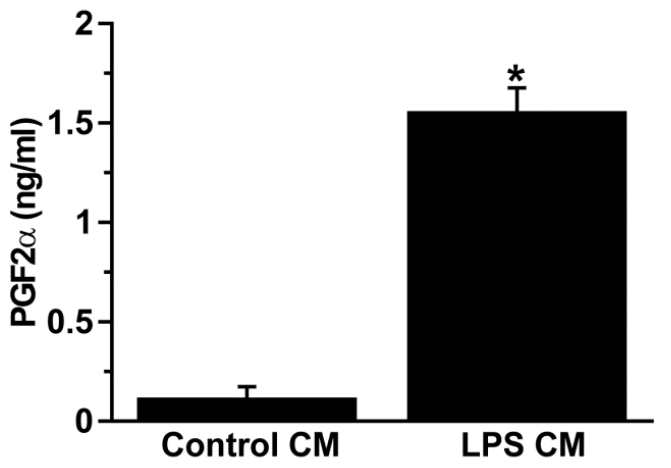

B

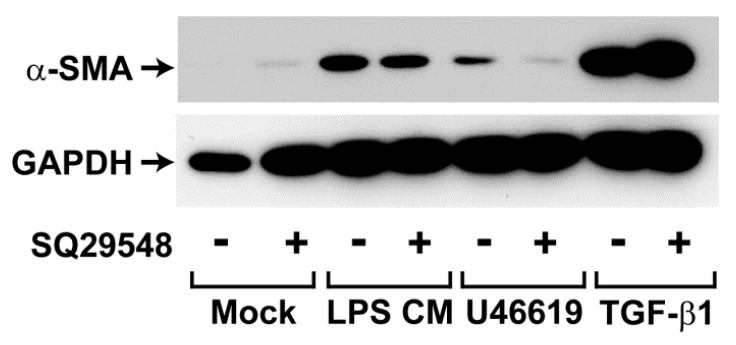

Fig. 4. LPS-activated macrophages secrete PGF2a (A) Macrophages were exposed to serum-free medium containing either vehicles or $5 \mathrm{ng} / \mathrm{ml}$ LPS for 2 days and the conditioned medium was then subjected to EIA for determination of the levels of PGF2a Data are expressed as mean \pm SD $(n=4),{ }^{*}, p<005$ vs control CM (B) Serum starved hMSCs were pretreated with vehicle or $10 \mu \mathrm{M}$ SQ29548 for $15 \mathrm{~min}$, and challenged with either $1 \mu \mathrm{M}$ U46619, 5\% LPS CM, or $1 \mathrm{ng} / \mathrm{ml}$ TGF- $\beta 1$ for 4 days The expression levels of a-SMA and GAPDH were determined by Western blot analysis. 
A

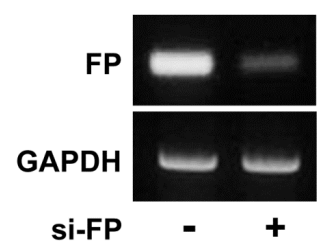

B

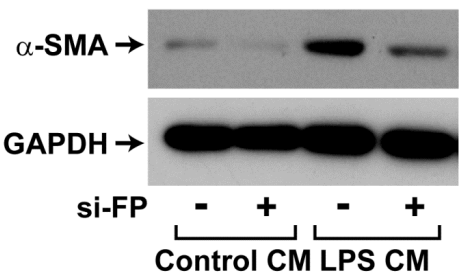

Fig. 5. Effect of prostaglandin F receptors in the LPS CM-induced expression of a-smooth muscle actin The siRNA-transfected hMSCs were treated with vehicles or 5\% LPS CM for 4 days The expression levels of a-SMA and GAPDH were determined by Western blot analysis.

siRNA를 이용하여 FP를 선택적으로 억제시키면 PGF2a에 의 해 증가되었던 a-SMA발현이 억제되는 것을 확인하였다[15]. 중간엽 줄기세포에 $\mathrm{FP}$ 수용체에 특이적인 siRNA를 이용해 $\mathrm{FP}$ 를 억제시킨 후 LPS 배양액을 처리하면, LPS 배양액에 의해 증가되었던 $\mathrm{a}-\mathrm{SMA}$ 의 발현이 $\mathrm{FP}$ 의 억제를 통해 $\mathrm{a}-\mathrm{SMA}$ 의 발 현이 현저히 감소되는 것을 확인하였다(Fig. $5 \mathrm{~B})$. 이러한 결과 를 통하여 LPS 배양액에 의한 a-SMA의 발현에는 PGF2a에 의한 것임을 확인할 수 있었다.

본 연구결과를 종합해 보면 LPS에 의해 활성화된 대식세 포는 PGF2a의 분비를 촉진 시키고 분비된 PGF2a에 의해 중 간엽 줄기세포는 평활근 세포로의 분화가 유도되는 것을 확 인하였다.

\section{Acknowledgement}

This work was supported for two years by Pusan National University Research Grant.

\section{References}

1. Barry, F. P. and Murphy, J. M. 2004. Mesenchymal stem cells: clinical applications and biological characterization. Int $J$ Biochem Cell Biol 36, 568-584.

2. Choi, K. U, Yun, J. S., Lee, I. H., Heo, S. C., Shin, S. H., Jeon, E. S., Choi, Y. J., Suh, D. S., Yoon, M. S. and Kim, J. H. 2011. Lysophosphatidic acid-induced expression of periostin in stromal cells: Prognoistic relevance of periostin expression in epithelial ovarian cancer. Int J Cancer 128, 332-342.

3. Delanty, N., Reilly, M. P., Pratico, D., Lawson, J. A., McCarthy, J. F., Wood, A. E., Ohnishi, S. T., Fitzgerald, D. J. and FitzGerald, G. A. 1997. 8-Epi PGF $_{2 a}$ generation during coronary reperfusion: A potential quantitative marker of oxidant stress in vivo. Circulation 95, 2492-2499.

4. Fairweather, D. and Rose, N. R. 2005. Inflammatory heart disease: a role for cytokines. Lupus 14, 646-651.
5. Geng, Y., Fang, M., Wang, J., Yu, H., Hu, Z., Yew, D. T. and Chen, W. 2011. Triptolide down-regulates COX-2 expression and PGE2 release by suppressing the activity of NF- $\mathrm{kB}$ and MAP kinases in lipopolysaccharide-treated PC12 cells. Phytother Res 26, 337-343.

6. Hoch, A. I., Binder, B. Y., Genetos, D. C. and Leach, J. K. 2012. Differentiation-dependent secretion of proangiogenic factors by mesenchymal stem cells. PLOS ONE 7, e3557.

7. Hong, H. S., Kim, Y. H. and Son, Y. 2012. Perspectives on mesenchymal stem cells: Tissue repair, immune modulation, and tumor homing. Arch Pharm Res 35, 201-211.

8. Jeon, E. S., Heo, S. C., Lee, I. H., Choi, Y. J., Park, J. H., Choi, K. U., Park, D. Y., Suh, D. S., Yoon, M. S. and Kim, J. H. 2008. Ovarian cancer-derived lysophospahtidic acid stimulates secretion of VEGF and stromal cell-derived factor-1 alpha from human mesenchymal stem cells. Exp Mol Med 42, 280-293.

9. Jeon, E. S., Lee, I. H., Heo, S. C., Shin, S. H., Choi, Y. J., Park, J. H., Park, D. Y. and Kim, J. H. 2010. Mesenchymal stem cells stimulate angiogenesis in a murine xenograft model of A549 human adenocarcinoma through an LPA1 receptor-dependent mechanism. Biochim Biophys Acta 1801, 1205-1213.

10. Jeon, E. S., Moon, H. J., Lee, M. J., Song, H. Y., Kim, Y. M., Cho, M., Suh, D. S., Yoon, M. S., Chang, C. L., Jung, J. S. and Kim, J. H. 2008. Cancer-derived lysophosphatidic acid stimulates differentiation of human mesenchymal stem cells to myofibroblast-like cells. Stem Cells 26, 789-797.

11. Joh, E. H., Jeong, J. J. and Kim, D. H. 2012. Kalopanaxsaponin B inhibits LPS-induced inflammation by inhibiting IRAK1 Kinase. Cellular Immunol 279, 103-108.

12. Kim, M. R., Jeon, E. S., Kim, Y. M., Lee, J. S. and Kim, J. H. 2009. Thromboxane $A_{2}$ induces differentiation of human mesenchymal stem cells to smooth muscle-like cells. Stem Cells 27, 191-199.

13. Kotanidou, A., Xagorari, A., Bagli, E., Kitsanta, P., Fotsis, T., Papapetropoulos, A. and Roussos, C. 2002. Luteolin reduces lipopolysaccharide-induced lethal toxicity and expression of proinflammatory molecules in mice. AmJ Respir Crit Care Med 165, 818-823.

14. Lee, M. J., Jeon, E. S., Lee, J. S., Cho, M., Suh, D. S., Chang, C. L. and Kim, J. H. 2008. Lysophosphatidic acid in malignant ascites stimulates migration of human mesenchymal stem cells. J Cell Biochem 104, 499-510.

15. Lee, M. J., Kim, M. Y., Heo, S. C., Kwon, Y. W., Kim, Y. M., Do, E. K., Park, J. H., Lee, J. S., Han, J. and Kim, J. H. 2012. Macrophages regulate smooth muscle differentiation of mesenchymal stem cells via a prostaglandin F2a -mediated paracrine mechanism. Arterioscler Thromb Vasc Biol 32, 2733-2740.

16. Li, W., Ren, G., Huang, Y., Su, J., Han, Y., Li, J., Chen, X., Cao, K., Chen, Q., Shou, P., Zhang, L., Yuan, Z. R., Roberts, A. I., Shi, S., Le, A. D. and Shi, Y. 2012. Mesenchymal stem cells: a double-edged sword in regulating immune responses. Cell Death Differ 19, 1505-1513.

17. Miller, F. D. and Kaplan, D. R. 2012. Mobilizing endogenous 
stem cells for repair and regeneration: Are we there yet? Cell Stem Cell 10, 650-652.

18. Moncada, S. 1999. Nitric oxide: discovery and impact on clinical medicine. J R Soc Med 92, 164-169.

19. Park, D., Spencer, J. A., Koh, B. I., Kobayashi, T., Fujisaki, J., Clemens, T. L., Lin, C. P., Kronenberg, H. M. and Scadden, D. T. 2012. Endogenous Bone Marrow MSCs Are Dynamic, Fate-Restricted Participants in Bone Maintenance and Regeneration. Cell Stem Cell 10, 259-272.

20. Pittenger, M. F., Mackay, A. M., Beck, S. C., Jaiswal, R. K., Douglas, R., Mosca, J. D., Moorman, M. A., Simonetti, D. W., Craig, S. and Marshak, D. R. 1999. Multilineage potential of adult human mesenchymal stem cells. Science 284, 143-147.

21. Prockop, D. J. 1997. Marrow stromal cells as stem cells form nonhematopoietic tissue. Science 276, 71-74.

22. Prockop, D. J. and Oh, J. Y. 2012. Mesenchymal Stem/Stromal Cells (MSCs): Role as Guardians of Inflammation. Mol Ther 20, 14-20.

23. Short, B., Brouard, N., Occhiodoro-Scott, T., Ramakrishnan, A. and Simmons, P. J. 2003. Mesenchymal stem cells. Arch Med Res 34, 565-571.

24. Takahashi, K., Nammour, T. M., Fukunaga, M., Ebert, J., Morrow, J. D., Roberts, L. J. 2nd, Hoover, R. L. and Badr,
K. F. 1992. Glomerular actions of a free radical-generated novel prostaglandin, 8-epi-prostaglandin F2 alpha, in the rat: Evidence for interaction with thromboxane A2 receptors. J Clin Invest 90, 136-141.

25. Utar, Z., Majid, M. I., Adenan, M. I., Jamil, M. F. and Lan, T. M. 2011. Mitragynine inhibits the COX-2 mRNA expression and prostaglandin E2 production induced by lipopolysaccharide in RAW264.7 macrophage cells. $J$ Ethnopharmacol 136, 75-82.

26. Vu, H. V., Acosta, T. J., Yoshioka, S., Abe, H. and Okuda, K. 2012. Roles of prostaglandin F2alpha and hydrogen peroxide in the regulation of Copper/Zinc superoxide dismutase in bovine corpus luteum and luteal endothelial cells. Reprod Biol Endocrinol 10, 87.

27. Yun, D. H., Song, H. Y., Lee, M. J., Kim, M. R., Kim, M. Y., Lee, J. S. and Kim, J. H. 2009 Thromboxane $\mathrm{A}_{2}$ modulates migration, proliferation, and differentiation of adipose tissue-derived mesenchymal stem cells. Exp Mol Med 41, 17-24.

28. Zhang, J. J., Xu, Z. M., Chang, H., Zhang, C. M., Dai, H. Y., Ji, X. Q., Li, C. and Wang, X. F. 2011. Pyrrolidine dithiocarbamate attenuates nuclear factor- $\mathrm{\kappa B}$ activation, cyclooxygenase-2 expression and prostaglandin E2 production in human endometriotic epithelial cells. Gynecol Obstet Invest $72,163-168$.

\section{초록 : 중간엽 줄기세포의 평활근 세포로의 분화에서 LPS에 의해 활성화된 대식세포의 역할 \\ 이미정 · 도은경 · 김재호* \\ (부산대학교 의학전문대학원 생리학교실)}

인체 중간엽 줄기세포는 지방세포, 골세포, 연골세포, 근육세포 등 여러 형태의 세포로의 분화되는 것이 특징 이다. 특히, 최근 연구 결과를 살펴 보면, 중간엽 줄기세포는 생체 내에서 조직 특이적인 세포 형태로 분화 된다. 본 연구에서는 염증 상태에 존재하는 중간엽 줄기 세포가 혈관 형성에 관여하는지 알아보고, 염증 상태에 존재하 는 줄기세포의 역할을 규명하고자 본 연구를 진행하였다. 생체 내 염증 상태와 유사한 환경을 만들고자, 강력한 염증 유발 물질인 LPS를 대식세포에 처리하여 그 배양액을 중간엽 줄기세포에 처리하여 변화를 관찰하였다. LPS 배양액을 처리한 중간엽 줄기세포는 평활근 세포로 분화가 촉진되는 것을 확인하였으며, LPS 배양액에 존재하는 분화 유도 물질이 PGF2a임을 확인하였다 이에 본 연구결과를 통해 염증 상태에서 존재하는 중간엽 줄기세포는 평활근 세포로의 분화가 촉진되는 것을 확인하였다. 본 연구는 염증성 미세환경 내에 존재하는 중간엽 줄기세포 가 평활근 세포로 분화가 유도됨을 확인하였고, 혈관 형성을 촉진하는데 영향을 미칠 수 있음을 제시한다. 